Александра Корда-Петровић

Универзитет у Београду

Филолошки факултет

Катедра за славистику

korda@verat.net
УДК 821.162.3-2.09

https://doi.org/10.18485/slavistika.2018.22.2.21

оригинални научни рад

примљено 22.02.2018.

прихваћено за штампу 04.10.2018

\title{
ТЕНДЕНЦИЈЕ У САВРЕМЕНОЈ ЧЕШКОЈ ДРАМИ
}

Савремена чешка драма за сада је недоступна српским читаоцима и позоришној публици. У раду се скицирају њене основне тематске и формалне одлике. Ауторска усмерења чешких драмских писаца сагледана су на примерима савремених драма које се ослањају на прошлост, драма са савременом тематиком, постмодерне политичке сатире и гротеске, чешке „нове драме“, као и драме које одликују лирске тенденције.

Кључне речи: чешка драма, нове тенденције, савремена тематика, формалне карактеристике, карактеристичне и универзалне одлике.

Modern Czech drama has so far been unavailable to the Serbian readers and theatre audiences. The paper outlines its basic thematic and formal characteristics. The directions of Czech dramatic writers are shown through the examples of modern dramas that rely on the past, dramas with modern themes, postmodern political satires and grotesques, Czech "new dramas" and dramas characterised by lyrical tendencies.

Key words: Czech drama, new tendencies, modern themes, formal characteristics, characteristic and universal characteristics.

Прегледом библиографије објављених књижевних превода са чешког на српски језик од 2000. године до данас, ${ }^{1}$ може се уочити потпуни изостанак превода чешких савремених драма. Ова чињеница заслужује посебну пажњу јер су последњих деценија 20. века драме Вацлава Хавела и Павела Кохоута имале велики успех управо у нашој средини. Дела ових чешких дисидентских аутора у нашим позориштима имала су своје европске премијере ${ }^{2}$ и била су читана, ${ }^{3}$ док новија чешка драма остаје непозната српској публици. Осим једног поновљеног издања превода драме Р.У.P Карела Чапека, ${ }_{4}^{4}$ која је један од првих примера научне фикције у драмском тексту, продукција новије објављених драмских дела у Чешкој није превођена на српски језик. Разлоге можемо тражити у чињеници што издавачи никада нису били наклоњени објављивању драмских текстова, пре свега због њихове природне повезаности са позоришним инсценацијама, али значајан је и податак да се модерни драмски текстови селективно објављују и у Чешкој, те су самим тим и мање доступни. Тек понека гостујућа представа, углавном у оквиру позоришних фестивала, ${ }^{5}$ могла је нашој публици да пружи

${ }^{1}$ Библиографија превода са чешког сачињена је уз помоћ COOBISS.SR, кооперативног онлајн библиографског система и сервиса.

${ }^{2}$ Више у А. Корда-Петровић, Феномен прихваћености чешких дисидентских аутора y српској средини, Зборник Матице српске за славистику 73, Нови Сад 2008, стр. 227-239.

${ }^{3}$ Познати су избори драма Вацлава Хавела Шест драма (Нолит, 1991) и Пазите! (Дечје новине, 1990) обе у избору и преводу Александра Илића. Ј. Илића.

${ }^{4}$ Карел Чапек Р.У.P (Београд: Центар за промоцију науке, 2012), у преводу Ненада

${ }^{5}$ Пример је гостовање представе Еуропеана у режији Јана Микулашека, по тексту Па- 
слику о тенденцијама савременог чешког драмског стваралаштва. У том смислу, циљ овог рада је да барем у основним цртама представи тенденције и перспективе савремене чешке драме.

Актуелно стање у чешкој савременој драмској књижевности потребно је сагледати у ширем контексту, са освртом на претходни период. На крају друге декаде трећег миленијума запажа се да је оригинално драмско стваралаштво донекле угрожено настојањима да се на позоришној сцени реализују већ познати филмски наслови, а изразита је и тенденција драматизација популарне књижевности. И у другим културама данас јача тренд инспирације филмским сценаријима, а драматизација познатих прозних дела има своје корене у раду представника такозване „неправилне драматургије“, 6 којој се прибегавало још у време тоталитарног режима. Циљ је био да забрањена дела заобилазним путем буду представљена публици. Као пример може послужити драматизација новеле Бохумила Храбала Служио сам енглеског краља, написана осамедесетих година и објављена у цензурисаној верзији, да би затим била постављена у нецензурисаној верзији на брњенској сцени Divadlo na provázku. ${ }^{7}$ Пример су и популарне аудио адаптације Хавелових драма Largo desolato и Asanace, које нису смеле да се изводе на позорници. До краја осамдесетих година прошлог века, ауторско драмско стваралаштво неговале су углавном мање, алтернативне сцене. Пример je Divadlo Járy Cimrmana, познато по глумачком тандему Здењек Свјерак и Ладислав Смољак, где се изводио циклус представа, импровизованих драмских мистификација, које су гротескним хумором и интелигентном иронијом исмевале режим, али и стање у конвенционалном, прорежимском позоришту тадашње Чехословачке. Тих година важну улогу имале су и мање позоришне сцене у Брну, Divadlo na provázku и Ha Divadlo, као и Činoherní studio у Усти над Лабем.

Последња деценија 20. века означена је као период кризе чешког драмског стваралаштва (Kerbr 2014). Квалитетни и у свету признати драмски писци, које је комунистички режим прогањао, пре свих Вацлав Хавел и Милан Ухде, заузимају државне позиције или престају да пишу драме. Један од ретких бивших дисидената који се после политичких промена враћа у земљу и наставља да пише, био је Павел Кохоут. Требало је испунити настали „празан простор“. Велика тема критике тоталитаризма, коју су неговали забрањени дисидентски аутори, није више била актуелна. Било је потребно вратити публику у позориште (Jungmanová, Vodička 2016). Измениле су се и опште околности у вези са функционисањем позоришних институција, које су све више морале да прелазе на алтернативне начине финансирања, као и да се прилагоде новим законима неолибералног тржишта у области културе. Позитиван импулс у том смислу имало је увођење конкурса за Награду Алфреда Радока (Cena Alfréda Radoka),

трика Оуржедњика. Предаставу је извело Divadlo Na Zábradlí из Прага у оквиру БИТЕФ-а 2013. године. Пре тога 20 година није било чешке представе на овом фестивалу.

${ }^{6}$ Појам „неправилна драматургија“ (nepravidelná dramaturgie) увео је театролог и драматург брњенског Divadla na provázku Борживој Срба, и односи се на адаптације текстова који нису драмски.

${ }^{7}$ Ово позориште у Брну основано је 1967. под називом Husa na provázku (Гуска на конопцу), али је под притиском цензуре по доласку на власт Густава Хусака, званично променило име на Divadlo na provázku. Разлог су биле честе уличне акције дописивања председниковог имена на плакатима овог позоришта. 
награде за најбољу ауторску чешку или словачку драму. Акцију је покренуо чаcoпис „Svět a divadlo“ 1992. године. Ова награда покренула је формирање нове генерације драмских писаца, од којих је већина била и праксом везана за позориште (нпр. позоришни редитељи Арношт Голдфлам, Мирослав Кробот, Јан Антоњин Питински, Јиржи Покорни, Мартин Франтишек и други).

Чешка ауторска драма од 90-их година прошлог века развија се у неколико праваца које диктирају не само различите позоришне тенденције, већ и посебна ауторска опредељења драмских писаца. Позоришни критичари и теоретичари настоје да систематизују савремене тенденције у чешком драмском стваралаштву. Тако у брошури чешког Министарсва за културу под називом Nové české drama (2000-2013) (Нова чешка драма 2000-2013), наилазимо на поделу савремених чешких драмских текстова према тематском критеријуму. Тако се издвајају савремене драме које се баве темама из даље и ближе прошлости тј. обраћају се садашњости посредством тумачења догађаја из прошлости, или се баве прерадом историјских тема (Jungmanová, Vodička 2016). У њима историјска грађа представља основу драмске фабулације, а у првом плану је напетост између прошлости и садашњости. Класична историјска драма се скоро изгубила, док драмски писци све више преиспитују општеприхваћене историјске чињенице. Драмски текстови подсећају на апокрифе, као и на прераде познатих митова и сижеа који одговарају потребама постмодерне поетике. Пример je драма Олдржиха Дањка, која на необичан начин разматра период владавине Карела IV (Oldřich Daňka: Jak snadné je vládnout aneb Karel IV - autoportrét, 1993). У њој се преиспитује стереотипна слика о овом владару која се негује у колективној свести чешког народа. Чињенице из новије историје, пре свега из периода социјализма, преиспитују се и поново вреднују тј. представљају одређену форму суочавања са историјском траумом. Таква је драма Михала Лазњовског у којој су осликане педесете године прошлог века кроз визуру дечака који одраста у хришћански оријентисаној породици и суочава се са супротно опредељеним окружењем (Michal Lázňovský: Hřich, 1993). Ту спада и драма Данијеле Фишерове у којој се педесете године политичке репресије рефлектују на живот једне породице (Daniela Fischerová: Andělský smích, 1994) или драма Милана Ухде, у којој се попут слике у огледалу рефлектују два тоталитарна система, нацизам и комунизам (Milan Uhde: Zázrak v černém domě, 2007).

Издваја се посебан круг драма са савременом тематиком, у којима се рефлектује друштво у транзицији, са свим својим деформацијама и пропалим илузијама. Као централни проблем издваја се конфронтација појединца са посттоталитарним системом, а пример је драма Антоњина Маше Чудне птице (Antonín Máša: Podivní ptáci, 1996), у којој је реч о бившем новинару који после 1989. одлази на село како би избегао замку нових богаташа. Ту спада и драма Данијеле Фишерове (Daniela Fischerová: Fantomima, 1995), која је посвећена судском процесу покренутом због саобраћајне несреће, процесу у коме главни јунак губи идентитет у лавиринту „демократског“ правосуђа. У ову групу спада и последња драма Вацлава Хавела Одлазак (Odcházení, 2008), која кроз пројекцију личног искуства покреће тему трауме одласка са власти, док се истовремено драматуршки ослања на Чеховљев Вищъик (радња се дешава у безвременском простору, главни сукоб је у позадини, а у првом плану су само су- 
коби на микроплану). На ову групу драма надовезује се постмодерна политичка сатира, која се углавном суочава са комунистичком прошлошћу и последицама недовољног обрачуна са злочинима бившег режима. Тако се у драмама као протагонисти појављују бивши колаборанти који данас заузимају важне позиције у друштву (Karel Steigerwald: Nobel, 1994).

Постмодерна гротеска издваја се као још један круг чешке савремене драме. То су драме које реинтерпретирају слику света, деконструишу старе односе, користе жанровски синкретизам. Трагична прича се приказује у форми гротеске, а аутори се често ослањају на интертекстуалне уметке који на другом нивоу комуницирају са читаоцем или публиком. Честа тема су медији, посматрани као средство дехуманизације, лаке забаве и кича. Аутори бирају поступке карактеристичне за друге медије нпр. телевизијске серијале, ситкоме и програме који се надовезују на поступак постдраматургије. Тако настаје мноштво поджанровски обликованих драма. Духовни отац чешке постмодерне гротеске je Арношт Голдфлам (Arnošt Goldflam), који у својим драмама користи елементе тривијалне књижевности, брише границу између трагедије и комедије, реалности и фикције, стварности и илузије, озбиљног и баналног (Lásky den, 1994; Ředitelská lóže, 2004; U Hitlerů v kuchyni, 2007). Гротескна слика деструкције друштва представљена је у драми Јиржија Кратохвила (Jiří Kratochvil: A babička slavi devětadevadesáté narozeniny aneb Rozhlasová balada o Smrti a o Jankovi, 1997), у којој је главни лик слављеница која дочекује стоту годину живота, цинична старица, која би могла бити и персонификација 20. века. Нове, постмодернистичке поступке у својим драмама користи Јан Антоњин Питински, који у драми под називом Собичак (Jan Antonín Pitínský: Pokojičcek, 1993) представља патологију савремених породичних односа, а сложена психолошка прича одвија се у типичном простору стамбене вишеспратнице.

Средином деведесетих формира се нова генерација драматурга који нису желели да личе на своје претходнике. Од реалистичке психологизације, сатиричне апсурдности или пренаглашене и разигране постмодерне, почели су да се окрећу према реалистичком опису, према политичким и социјалним темама, укључујући етничке, културне или родне разлике (Jungmanová, Vodička 2016: 12). Драме ових аутора нису се одликовале само садржинском окрутношћу, оштрином у ставу и отвореношћу, већ и драматуршком искључивошћу која често не допушта да се дело интерпретира другачије него дословно. У Европи је овај тип драме назван „нова драма“ а своју инспирацију има у филмовима и серијама (Тарантинов Pulp Fiction, Бојлов Trainspotting или анимирана серија South Park). Ову врсту драме неговао је Činoherní studio и брњенско Ha Divadlo, а главни носиоци су Јиржи Покорни (Jiří Pokorný) и Мирослав Бамбушек (Miroslav Bambušek). Овај приступ драмском тексту добија назив cool (coolness) драма, што означава специфичан тип драмских дела у којима се користе драстичне сцене које код гледалаца изазивају шок и језу. Девијантно понашање, хомосексуализам, драстични прикази секса и насиља, приказују свет који је хладан, без емоција, а бруталност има за циљ да провоцира публику.

Лирска тенденција савремене чешке драме издваја се као посебан тип психолошке драме (Vodička 2008: 581-586). Главна карактеристика је покушај искорачења из жанровског стереотипа трагикомичних и гротескних драма. 
У центру пажње је психолошки портрет појединца који није никакав социолошки или психолошки тип, већ представља непоновљиво биће. У таквим комадима преовладава тематизација осећаја празнине, отуђења и немогућност комуникације у свету који је дигитализован, медијски диригован и окренут потрошачким вредностима. У овим драмама се често нарушава драмска структура. Драмске ситуације нису повезане и често не постоје узрочно-последичне везе. Не постоји драмски конфликт, а у првом плану су асоцијативне и колажне ситуације кроз које се преплићу различити нивои реалности, снови и визије. Овакве драме често тематизују сложене породичне, генерацијске и партнерске конфликте, кроз које се рефлектују субјективна стања јунака. Пример је драма Антилопа Ленке Лагронове (Lenka Lagronová: Antilopa, 1995), осмишљена као низ асоцијативних визија, снова и реалних ситуација које се одигравају током разговора ћерке са мајком на умору при чему се откривају скривени слојеви тананих и деликатних односа.

Ленка Лагронова, Магдалена Фридрих Грегорова (Magdalena Frydrych Gregorová), Ива Клестилова (Iva Klestilová) и Радмила Адамова (Radmila Adamová) су ауторке које се у својим драмама баве питањем родне равноправности, откривају различите судбине жена, њихова разочарања, (не)успеле покушаје превазилажења стереотипа и врло често ови текстови имају ироничан подтекст ${ }^{8}$ (Machalická 2014).

У оквиру овог посебног типа драма настало је неколико драмских текстова који су у позоришним и стручним круговима изазвали полемику. Једни су у њима видели негирање основних поетских принципа структуре драмског текста и побуну против досадашњих стваралачких стереотипа и норми, док су други критиковали њихову бесмисленост и празнину (Vodička 2008). Тако је инсценација текста Егона Тобиаша Војцеев (Egon Tobiáš: Vojcev, 1992) изазвала бурну полемику у вези са границама ауторске слободе. Драмског текста овде има минимално, подељен је у триптих са прологом и епилогом, који се сижејно и формално разликују. Главна оса је променљиви идентитет протагониста: ликови мењају имена, негирају сами себе и међусобно се налазе у нејасним односима. Све је доведено до апсурдних граница, текст је тешко разумљив а извођење се своди на варијације и понављање текста. Значење самог текста овде игра све мању улогу и могли бисмо га сврстати у експериментални драмски текст, који трага за новим и другачијим значењима.

Иако наведени прикази и студије (Vodička 2008; Kerbr 2014; Machalická 2014) подвлаче чињеницу да су деведесете године прошлог века представљале период кризе ауторске чешке драме, увидом у различите позоришне тенденције и типове драмских текстова аутора који су се афирмисали током прве декаде овог века, можемо закључити да је криза превазиђена. Чини нам се да је потребно поставити питање: у коликој мери је чешка савремена драма створила своје карактеристичне посебности, сличне онима које је формирала осамдесетих година прошлог века као чешка дисидентска драма' ${ }^{9}$, као таква, била препознатљива ван граница своје културе?

${ }^{8}$ Пример је драма Радмиле Адамове Little Sister (2008), која је инспирисана телевизијским реалити програмом Big Brother.

9 Ту се мисли пре свега на драме Вацлава Хавела, Павела Кохоута, Ивана Климе, Франтишека Павличека и Милана Ухде. 
С једне стране, чешка драма задржала је препознатљиву посебност коју уочавамо у групи гротескних и сатиричних драма, а коју негују углавном позоришта кратке форме. Пример је Divadlo Járy Cimrmana, као и Divadlo Na zábradlí, у којима се постављају комади са упадљивим одликама црне комедије и гротеске, а у којима се типичним чешким цинизмом критикује стварност. С друге стране, променом тематских и формалних одлика, чешка савремена драма под великим је утицајем страних импулса, пре свега англо-америчке coolness драматургије и позоришних инсценација под утицајем немачког позоришта (Vodička 2008). Као и у другим драмским књижевностима, тако и у чешкој драми, јасно доминира поетика преузимања уметничких израза из других медија (филм, телевизија, књижевност, стрип, видео-игрице). Ипак, на тематском плану, чешка ауторска драма све више се помера од локалних тема рекапитулације прошлости и обрачуна са траумама из периода тоталитарног друштва, ка тематизацији негативних последица деструкције међуљудских односа и онтолошким питањима места појединца у глобалном свету. Таквим померањем ка општим, цивилизацијским или пак субјективним, психолошким проблемима, чешка драма постаје доступнија за рецепцију у другим срединама. Самим тим њено одсуство, како у преводима на српски језик, тако и на нашим позорницама, продубљује још више постојећу празнину.

\section{Цитирана литература}

Jungmannová, Lenka, Libor Vodička. České drama v letech 1989-2010. Praha: Akademie věd České republiky, 2016.

Kerbr, Jan. „Nové české drama včera, dnes (a zítra)“. [In:] R. Kopáč (ed.) Nové české drama (2000-2013). Praha: Miniserstvo kultury, 2014, 7-11.

Machalická, Jana. „Groteska, koláž, politika“. [In:] R. Kopáč (ed.) Nové české drama (2000-2013). Praha: Ministerstvo kultury, 2014, 24-38.

Vodička, Libor. „Obecná charakteristika situace divadelní kultury po roce 1989“. [In:] P. Hruška, L. Machala, L. Vodička, J. Zizler (eds.) V souřadnicích volnosti. Česká literatura 90. let XX století v interpretacích, Praha:Academia, 2008, 555-586.

\section{Aleksandra Korda Petrović}

\section{TENDENCIES IN THE MODERN CZECH DRAMA}

\section{Summary}

The modern Czech drama has retained its distinguishable features noticeable in a group of grotesque and satirical plays, usually incorporated in political satire. On the other hand, after the change of thematic and formal characteristics, the modern Czech drama is under immense influence from abroad, primarily the Anglo-American coolness dramaturgy and theatrical inscenations of the German theatre. It is dominated by the permeations of artistic expressions from other media (movies, television, literature, comics, and video games). However, in terms of themes, Czech written drama is moving away from local themes that deal with the past and confront the traumas from the period of totalitarian society and is moving towards the depiction of the negative consequences 
of the destruction of interpersonal relationships and the ontological question concerning the position of an individual in a global society. With this shift towards general, civilizational or subjective, psychological problems, Czech drama becomes more available for reception in other environments. Thus, its absence, both in terms of translations in the Serbian language and in terms of our theatres, deepens an already existing gap.

Key words: Czech drama, new tendencies, modern themes, formal characteristics, characteristic and universal characteristics. 